\title{
Food Management System and Satisfaction Level of Students of Pesantren Tebuireng Jombang, East Java
}

\author{
Mustamir Kamaruddin ${ }^{1,}$ Anwar Mallongi \\ ${ }^{1}$ Research Scholar Department of Nutrition, Health Polytechnic Ministry of Health, Sorong, Indonesia, \\ ${ }^{2}$ Professor of Department of Environmental Health, Faculty of Public Health, Hasanuddin University, Indonesia
}

\begin{abstract}
Efforts so that a person's nutritional needs can be obtained optimally is by holding a food that is managed by applying various scientific disciplines. This study aims to analyze the food delivery system and the level of satisfaction of students in Tebuireng Islamic Boarding School in Jombang, East Java. This research was observational with a cross-sectional study design. Samples taken are students who live and or boarding at Tebuireng Islamic Boarding School in Jombang, East Java, with a total of 303 people from the class 2 population. Samples were taken using total sampling. Data collection is done by providing an identity questionnaire, satisfaction test form sheets and interviews with foodservice parties. The results showed that the food delivery system at Tebuireng Islamic Boarding School in Jombang in East Java was already good in management, service, and workflow but there were still shortages, such as the proportion of students and catering service staff that was not appropriate, there was no calculation of individual student needs, and food handlers hygiene knowledge still needs to be improved. The level of satisfaction of students to the overall menu of students with a thin nutritional status of $76.36 \%$ with the category "Satisfied"; students with normal nutritional status of $67.79 \%$ with the category "Dissatisfied"; and students with fat nutritional status of $64.49 \%$ with the category "Dissatisfied". Training regarding sanitation and hygiene is good and right during the process of providing food and training on how to process various kinds of menus from one food item.
\end{abstract}

Keywords: Food Management, Level of Satisfaction, Santri

\section{Introduction}

The nutritional and health status of mothers and children as a determinant of the quality of human resources is increasingly evident by the evidence that the nutritional and maternal health status in pre-pregnancy, during pregnancy, and during breastfeeding is a very critical period. The thousand-day period, which is 270 days during pregnancy and 730 days in the baby's first life, is sensitive because the effects on the baby at this time will be permanent and cannot be corrected. The impact is not only on physical growth but also on mental development and intelligence, which in adulthood can be seen from the physical size that is not optimal and the quality of work that is not competitive resulting in low economic productivity ${ }^{1}$

Inadequate nutrition can potentially inhibit sexual growth and maturation, although this may be the result of chronic malnutrition in infancy and childhood. And can place them at high risk of chronic diseases (risk of type 2 diabetes, hypertension, dyslipidemia, and carotidarterial atherosclerosis) especially if combined with adverse lifestyle others. Deficiency or excess nutrients will be manifested in the form of growth that deviates from the standard pattern ${ }^{2-4}$.

To maintain the quality of the food served, the food served must be evaluated one of the ways is to calculate the acceptability of consumer food. Food acceptance is the percentage of food consumed from the total amount provided $^{5-6}$. This acceptance is influenced by several factors including the appearance of food when served and the taste of food. This study aims to analyze the food delivery system and the level of satisfaction of students in Tebuireng Islamic Boarding School in Jombang, East Java. 


\section{Materials and Method}

\section{Population and Sample}

The population in this study is the food delivery unit in Tebuireng Islamic Boarding School in Jombang, East Java and all students in the Tebuireng Islamic Boarding School in Jombang, East Java. The students referred to in this study are students living and or boarding at Tebuireng Islamic Boarding School in Jombang, East Java. Sampling is done by total sampling from the target population. The target population is class II, junior high school, Islamic junior high schools, high school, and Islamic high school as many as 521 people. The sample used was a total sampling of 303 people.

\section{Data Collection}

Data collection was obtained by conducting direct interviews with food service managers and respondents by referring to the questionnaire that was available that contained questions and statements to explore information about the variables to be analyzed which are closely related to the food delivery system and satisfaction.

\section{Data Analysis}

Data analysis using IBM SPSS Statistics 21. Univariate analysis was carried out to get a general picture by describing each variable used in the study by looking at the description of the frequency distribution in tabular form. Bivariate analysis was performed using chi-square to see individual characteristics of the level of satisfaction.

\section{Results}

The food management unit in the Islamic boarding school in the making of the menu does not see the habits of the students and employees (Table 1), menus are made based on a predetermined expenditure budget, for example like there is a fried chili sauce menu of tempeh not all students have the habit of consuming tofu and tempeh because of students not only from Jombang Regency but from various regions in Java and some even from outside Java.

Table 1: Process Component Analysis at Tebuireng Islamic Boarding School in Jombang, East Java

\begin{tabular}{|c|c|c|c|}
\hline No & Item & Yes & No \\
\hline 1. & Budget Financing & $\ddot{\mathrm{u}}$ & \\
\hline 2. & Budget Planning & $\ddot{\mathrm{u}}$ & \\
\hline 3. & Santri factor (calculates the nutritional adequacy of students) & & $\ddot{\mathrm{u}}$ \\
\hline 4. & $\begin{array}{l}\text { Eating habits (planned menus according to student eating habits, food } \\
\text { habits) }\end{array}$ & & $\ddot{\mathrm{u}}$ \\
\hline 5. & $\begin{array}{l}\text { Kitchen utensils and equipment available (if the equipment is limited to a } \\
\text { simple planned menu) }\end{array}$ & $\ddot{\mathrm{u}}$ & \\
\hline 6. & Number of employees (1 employee for 8-10 students) & & $\ddot{u}$ \\
\hline 7. & $\begin{array}{l}\text { The amount of food received must be the same as the amount of food } \\
\text { written on the purchase invoice and the same as the demand for the } \\
\text { boarding school }\end{array}$ & $\ddot{\mathrm{u}}$ & \\
\hline 8. & $\begin{array}{l}\text { The quality of food received must be by the specifications of the food } \\
\text { requested at the time of purchase }\end{array}$ & $\ddot{\mathrm{u}}$ & \\
\hline
\end{tabular}


Cont... Table 1: Process Component Analysis at Tebuireng Islamic Boarding School in Jombang, East Java

\begin{tabular}{|c|c|c|c|}
\hline 9. & $\begin{array}{l}\text { The price of food items listed on the purchase invoice must be the same as } \\
\text { the price of food items listed on the food supply offer. }\end{array}$ & $\ddot{\mathrm{u}}$ & \\
\hline 10. & $\begin{array}{l}\text { Dry food container (rice, sugar, flour, green beans, oil, soy sauce, canned } \\
\text { food, etc.) }\end{array}$ & $\ddot{\mathrm{u}}$ & \\
\hline 11. & Fresh food container (meat, poultry, vegetables, and fruit) & $\ddot{\mathrm{u}}$ & \\
\hline 12. & $\begin{array}{l}\text { There is equipment needed (mechanical tools, containers of various sizes, } \\
\text { cooking utensils including stoves, pans, pans, cutters in various sizes in } \\
\text { good condition) }\end{array}$ & $\ddot{\mathrm{u}}$ & \\
\hline 13. & $\begin{array}{l}\text { Recipe standards include the size of the food ingredients, seasonings } \\
\text { needed, cooking methods and techniques for each type of cuisine. }\end{array}$ & $\ddot{\mathrm{u}}$ & \\
\hline 14. & $\begin{array}{l}\text { Preparing spices (onion, garlic, ginger nutmeg, kaempferia galanga, } \\
\text { coriander, cumin, pangi, galanga, lemongrass, chilies, and tomatoes) with } \\
\text { mashed /ground, thinly sliced and crushed techniques. }\end{array}$ & $\ddot{\mathrm{u}}$ & \\
\hline 15. & Food that will be processed is fresh, not rotten and not withered & $\ddot{u}$ & \\
\hline 16. & Using the right way of cooking food & & $\ddot{u}$ \\
\hline 17. & The clothes used are brightly colored & $\ddot{u}$ & \\
\hline 18. & Clothing that is used in a clean state & $\ddot{u}$ & \\
\hline 19. & Hand nails are short and clean & & $\ddot{\mathrm{u}}$ \\
\hline 20. & Hand nails are not painted & $\ddot{u}$ & \\
\hline 21. & Hands are always clean before touching food & $\ddot{u}$ & \\
\hline 22. & Hair in a neat and bound condition (not unraveled) or covered & $\ddot{\mathrm{u}}$ & \\
\hline 23. & Food handlers use aprons that are still clean & $\ddot{\mathrm{u}}$ & \\
\hline 24. & Do not use aprons as hand towels & $\ddot{u}$ & \\
\hline 25. & Food handlers use head cover to cover hair when processing food & & $\ddot{\mathrm{u}}$ \\
\hline 26. & Food handlers use food handlers when processing food ingredients & $\ddot{\mathrm{u}}$ & \\
\hline 27. & Food handlers use special gloves that are still clean when processing food & & $\ddot{u}$ \\
\hline
\end{tabular}




\begin{tabular}{|c|c|c|c|}
\hline 28. & Washing hands with clean water and soap each time will handle food & $\ddot{\mathrm{u}}$ & \\
\hline 29. & $\begin{array}{l}\text { Cover your mouth and nose with a handkerchief or special cloth when } \\
\text { sneezing or coughing }\end{array}$ & $\ddot{u}$ & \\
\hline 30 . & Do not pry ears and or nose at work & & $\ddot{\mathrm{u}}$ \\
\hline 31. & Do not hold dirty objects when working & $\ddot{\mathrm{u}}$ & \\
\hline 32. & Do not smoke while working & ü & \\
\hline 33. & The water used does not smell & $\ddot{u}$ & \\
\hline 34. & The water used is colorless and tasteless & $\ddot{u}$ & \\
\hline 35. & The water used for washing food utensils is running water & $\ddot{\mathrm{u}}$ & \\
\hline 36. & $\begin{array}{l}\text { There is a toilet with a door that is always closed and in a clean state } \\
\text { complete with soap }\end{array}$ & $\ddot{\mathrm{u}}$ & \\
\hline 37. & $\begin{array}{l}\text { Available bins in sufficient quantities and meet the requirements, namely } \\
\text { at least } 1 \text { trash can in each production room, waterproof, has a lid and } \\
\text { always cleaned every day }\end{array}$ & $\ddot{\mathrm{u}}$ & \\
\hline 38. & There is a sewerage that is smooth and waterproof. & $\ddot{\mathrm{u}}$ & \\
\hline
\end{tabular}

Based on the results of the menu analysis using CD Menu software, the most energy is found in the 4th-day menu with the amount of energy of $2597.8 \mathrm{kcal}$ and the least energy is the menu on the $3 \mathrm{rd}$ day which is $2111.3 \mathrm{kcal}$.

Table 2. Analysis of Output Components (Nutrition Value Menu) at Tebuireng Islamic Boarding School in Jombang, East Java

\begin{tabular}{|c|c|c|c|c|}
\hline \multirow[b]{2}{*}{$\begin{array}{l}\text { Menu } \\
\text { Days to }\end{array}$} & \multicolumn{4}{|c|}{ Nutritional Substances } \\
\hline & $\begin{array}{l}\text { Energy } \\
\text { (kcal) }\end{array}$ & Protein (gr) & $\begin{array}{l}\text { Fat } \\
\text { (gr) }\end{array}$ & $\begin{array}{l}\text { Carbohydrate } \\
\text { (gr) }\end{array}$ \\
\hline 1 & 2348 & 78,1 & 61,3 & 371,9 \\
\hline 2 & 2412,6 & 101,4 & 56,4 & 371,1 \\
\hline 3 & 2111,3 & 78,5 & 43,5 & 341,7 \\
\hline 4 & 2597,8 & 93,8 & 61,4 & 421,4 \\
\hline 5 & 2531,9 & 102,6 & 57,9 & 395,7 \\
\hline 6 & 2458,2 & 97,0 & 60,0 & 384,4 \\
\hline 7 & 2566,6 & 99,2 & 52,3 & 263,4 \\
\hline 8 & 2226,7 & 69,1 & 39,2 & 393,8 \\
\hline
\end{tabular}


Table 3. Frequency of Santri Characteristics in Tebuireng Islamic Boarding School in Jombang, East Java

\begin{tabular}{|c|c|c|c|c|c|c|}
\hline \multirow{3}{*}{ Characteristics } & \multicolumn{6}{|c|}{ Nutritional Status } \\
\hline & \multicolumn{2}{|c|}{ Thin } & \multicolumn{2}{|c|}{ Normal } & \multicolumn{2}{|c|}{ Fat } \\
\hline & $\mathrm{n}$ & $\%$ & $\mathrm{n}$ & $\%$ & $\mathrm{n}$ & $\%$ \\
\hline \multicolumn{7}{|l|}{ Age } \\
\hline $12-15$ year & 10 & 71.4 & 95 & 39.3 & 22 & 46.8 \\
\hline $16-18$ year & 4 & 28.6 & 147 & 60.7 & 25 & 53.2 \\
\hline Total & 14 & 100 & 242 & 100 & 47 & 100 \\
\hline \multicolumn{7}{|l|}{ Gender } \\
\hline Man & 11 & 78.6 & 147 & 60.7 & 22 & 46.8 \\
\hline Girl & 3 & 21.4 & 95 & 39.3 & 25 & 53.2 \\
\hline Total & 14 & 100 & 242 & 100 & 47 & 100 \\
\hline \multicolumn{7}{|l|}{ Origin } \\
\hline Bali & 0 & 0.0 & 3 & 1.2 & 1 & 2.1 \\
\hline Banten & 0 & 0.0 & 8 & 3.3 & 1 & 2.1 \\
\hline Bengkulu & 0 & 0.0 & 1 & 0.4 & 0 & 0.0 \\
\hline DKI Jakarta & 0 & 0.0 & 15 & 6.2 & 1 & 2.1 \\
\hline Jabar & 2 & 14.3 & 21 & 8.7 & 10 & 21.3 \\
\hline Jambi & 0 & 0.0 & 2 & 0.8 & 0 & 0.0 \\
\hline Jateng & 1 & 7.1 & 31 & 12.8 & 7 & 14.9 \\
\hline Jatim & 10 & 71.5 & 138 & 57.0 & 25 & 53.2 \\
\hline Jogyakarta & 0 & 0.0 & 3 & 1.2 & 0 & 0.0 \\
\hline Kalteng & 0 & 0.0 & 1 & 0.4 & 0 & 0.0 \\
\hline Kaltim & 0 & 0.0 & 2 & 0.8 & 1 & 2.1 \\
\hline Kalut & 0 & 0.0 & 1 & 0.4 & 0 & 0.0 \\
\hline Kepri & 0 & 0.0 & 1 & 0.4 & 0 & 0.0 \\
\hline Lampung & 1 & 7.1 & 3 & 1.2 & 0 & 0.0 \\
\hline Malut & 0 & 0.0 & 1 & 0.4 & 0 & 0.0 \\
\hline NTT & 0 & 0.0 & 1 & 0.4 & 0 & 0.0 \\
\hline Papbar & 0 & 0.0 & 1 & 0.4 & 0 & 0.0 \\
\hline Papua & 0 & 0.0 & 1 & 0.4 & 0 & 0.0 \\
\hline Riau & 0 & 0.0 & 1 & 0.4 & 0 & 0.0 \\
\hline Sulsel & 0 & 0.0 & 2 & 0.8 & 0 & 0.0 \\
\hline Sulteng & 0 & 0.0 & 2 & 0.8 & 0 & 0.0 \\
\hline Sumsel & 0 & 0.0 & 3 & 1.2 & 1 & 2.1 \\
\hline Total & 14 & 100 & 242 & 100 & 47 & 100 \\
\hline
\end{tabular}


Based on table 3, the respondents who were mostly aged between 12-15 years were in the normal nutritional status of $74.8 \%$; most respondents aged between $16-18$ years were at normal nutritional status that is $83.5 \%$.

Table 4. Distribution of Santri Satisfaction of the Entire Menu at Tebuireng Islamic Boarding School in Jombang, East Java

\begin{tabular}{|l|l|l|l|}
\hline $\begin{array}{l}\text { Overall Quality } \\
\text { Food Menu }\end{array}$ & \multicolumn{2}{l|}{ Nutritional Status } \\
\hline & Thin & Normal & Fat \\
\hline Score (\%) & 76,36 & 67,79 & 64,49 \\
\hline Category & Satisfied & Not Satisfied & Not Satisfied \\
\hline
\end{tabular}

Table 4 shows the level of satisfaction of students with the overall menu of students with nutritional status of $76.36 \%$ under the category of "Satisfied"; students with normal nutritional status of $67.79 \%$ with the category "Dissatisfied"; and students with fat nutritional status of $64.49 \%$ with the category "Dissatisfied".

\section{Discussion}

Employees also need to get adequate nutrition attention so that employee performance is expected to be optimal. According to $\mathrm{Marotz}^{7}$, nutritional needs are several nutrients needed by individuals to be able to live healthy and maintain their body condition. Adequacy of nutrition is the amount of each nutrient needed by individuals to live a healthy life. The nutritional adequacy of each person/individual varies according to age, sex, and level of activity.

According to Nurdiani $^{8}$, in the procurement of foodstuffs, there is a food procurement planning and market survey aimed at obtaining standardized foodstuff specifications according to size, type, size to maintain good quality foodstuffs. The market survey aims to find out the price of materials by specifications in the market as a basis for budget planning.

According to Kwon et $\mathrm{al}^{9}$, the reception of foodstuffs in the operation of food is carried out to ensure that food is received in a fresh and safe condition so that foodstuffs can be moved to the right place by the characteristics of these foodstuffs. It is known that the food operation unit already has a dry food storage area and has been separated between dry food ingredients and wet or fresh food items. This is by the statement of Bartono
\& Ruffino ${ }^{10}$, which states that the food ingredients are stored according to the appropriate types and conditions.

In preparing food ingredients must pay attention to the principle of maintaining and preventing loss of nutrients lost cooked, weeding, and washing food ingredients then cut them according to recipe instructions, carry out preparation techniques and mix herbs according to recipe instructions, prepare food ingredients and seasonings as little as possible with cooking.

In food processing, hygiene behavior is very much needed, including using the attributes of the headcover, mask, and gloves to avoid contamination of food. According to Damayanthi et $\mathrm{a}^{11}$, high levels of bacterial and microbial contamination of cutlery and food served openly. Therefore it is necessary to increase hygiene behavior for food handlers. One way to do hygienic behavior for food handlers is to wash hands before doing food processing activities. But food handlers must know good hygiene behavior. This is due to avoid contamination of food ${ }^{12}$.

Based on the results of menu analysis using CD Menu software, it is obtained the nutritional value of the menu per day in the menu cycle. The menu with the most energy is on the 4th-day menu with the amount of energy of $2597.8 \mathrm{kcal}$, while the least energy is the menu on the 3rd day which is $2111.3 \mathrm{kcal}$. Research conducted by Carrier $^{13}$ proves that menu cycles, modification of recipes, serving and packaging as well as ways of food distribution are significantly related to the incidence of malnutrition because it reduces food intake 
Customer satisfaction can be achieved if consumers feel all their needs are met and get good customer service. The results of this study are also consistent with the results of Mandasari \& Tama's ${ }^{14}$ research, which states that staff behavior including service friendliness is the most influential attribute on customer satisfaction.

African American adolescents have low consumption of vegetables and fruits, and they consume too much fried food and soft drinks: $55.1 \%$ consume twice or more fried foods every day and $19.5 \%$ four times or more daily day; $70.3 \%$ consumed soft drinks twice or more every day and $22.0 \%$ four times or more every day on average $\mathrm{e}^{15}$

\section{Conclusions}

The food delivery system at Tebuireng Islamic Boarding School in Jombang in East Java is good in management but the knowledge of food handlers' hygiene needs to be improved. In organizing food, it should consider aspects that can improve consumer appetite, namely variations in processing techniques, taste, flavor, color, size, shape of the dish cut, portions, and appearance of the presentation and training on how to process various kinds of menus from one food ingredient.

Ethical Cleanrence: from university ethical committee

Source of Funding : This publication was supported by the Health Polytechnic Ministry of Health, Sorong, Indonesia.

\section{Conlict of Interest : Nil}

\section{References}

1. Bappenas Republik Indonesia.. Gerakan Nasional Percepatan Perbaikan Gizi Dalam Rangka Seribu Hari Pertama Kehidupan. Diakses 28 February 2015. Available from : [http://www.bappenas. go.id/files/7713/8848/0483/KERANGKA_ KEBIJAKAN_-_10_Sept_2013.pdf]. 2013

2. Juonala, M., C. G. Magnussen, et al. Childhood adiposity, adult adiposity, and cardiovascular risk factors. New England Journal of Medicine 2011; 365(20): 1876-1885.

3. Mullan, B., C. Wong, et al. An examination of the demographic predictors of adolescent breakfast consumption, content, and context. BMC public health 2014; 14(1): 264.

4. Singh, J., P. Kariwal, et al. Assessment of nutritional status among adolescents: a hospital-based crosssectional study. International Journal of Research in Medical Sciences 2014; 2(2): 620-624.

5. Anwar Mallongi, Herlianti, Hasnawati Amqam, Dwia Aries Tina Pulubuhu, Muhammad Arsyad, Muh. Saleh Jastam, Muhammad Rachmat, Calculation of Potential Risks Assessment of Escherichia coli and Total Coliform in Communities Well Water of Puty Village, Luwu Regency. Indian Journal of Public Health Research \& Development, July 2019, Vol. 10, No. 7

6. Anwar Mallongi, Stang, Syamsuar, Hasnawati Amqam, Aminuddin Syam, Syahrul Basri, Muh. Saleh. Target Cancer Risks Due To The Exposure From Silica Among The Communities Living Surround Cement Tonasa Industry Pangkep, Indonesia. Interciencia Journal. 2019 44(11)

7. Marotz LR., Cross MZ., Rush JM.. Health, Safety, and Nutrition for Young Child 6th Edition. USA: The Thompson Corporation. 2005.

8. Nurdiani R. Analisis Penyelenggaraan Makanan di Sekolah dan Kualitas Menu bagi Siswa Sekolah Dasar di Bogor. (Tesis). Bogor : Program Pascasarjana, Institut Pertanian Bogor. 2011.

9. Kwon S., Bednar CM., Junehee K., \& Butler KA. An Investigation of College and University Food Service Administrators' Level of Agreement on Potential Influencing Factors on Sustainable Food Waste Management. Journal of Foodservice Management and Education, 2012; 6(2), 21-26.

10. Bartono \& Ruffino. Food and Product Management di Hotel dan Restoran. Yogjakarta: Penerbit Andi. 2005.

11. Damayanthi E., Yuliati L., Suprapti V., \& Sari F. Aspek Sanitasi dan Higiene di Kantin Asrama Tingkat Persiapan Bersama IPB. Jurnal Gizi dan Pangan, 2008; Vol 3(1), 22-29.

12. Benhura C., Nyagura SF., Gombiro PE., Dakwa F., \& Ngeyniyama P.. Food Service Quality Survey at The University of Zimbabwe Private Canteens. Journal of Food Science and Technology, 2012; Vol 4(5), 281-285.

13. Carrier N, D. Quellet, G.E West. Foodservice nutritional care and staffing are associated with the risk of malnutrition in long term care. Journal of 
the American Dietetic Association, Agustus 2007, supplement 3 abstracts volume 107 number 8: A 32.

14. Mandasari V \& Tama BA. Analisis kepuasan konsumen terhadap restoran siap saji melalui data mining. Jurnal Gnerei. 2011; Vol 6(1), 25-27.
15. Wang, Y., H. Liang, et al. Obesity and related risk factors among low socio-economic status minority students in Chicago. Public health nutrition 2007; 10(09): 927-938. 